ONITED STATES

DEPARTMENT OF THE INTERIOR

GEOLOGICAL SURVEY

Water Resources Division

GROUND-WATER INVENTORY FOR 1964,

EDWARDS AIR FORCE BASE, CALIFORNIA

By

F. W. Giessner and S. G. Robson

$65 \cdot 62$

Prepared in cooperation with the Department of the Alr Force

OPEN-FILE REPORT

$$
\begin{aligned}
& \text { Garden Grove, California } \\
& 1965 \\
& 10-21-65 \\
& \text { P.4 Follow's }
\end{aligned}
$$




\section{IIIUSTRATIOIS}

Paged

P1gure 1. Map of part of southern Callfornta showing

area described in this report-anom 9

2. Graph showling pumpage from wells at Edwards Alr

. Force Base, Callforman_ 13

3. Map of Edrards A1r Porce Base and Flcinity,

Calfeomia, showling geology, location of

wells, groundwater storage units, and

water-level contours for March 1965- 15

4. Bydrographs of wells $9 \mathrm{~N} / 10 \mathrm{~W}-12 \mathrm{R} 1$ and $9 \mathrm{~N} / 10 \mathrm{~W}-34 \mathrm{RI}-\ldots 15$

5. Graph shoulng estimated total depletion of ground water Ia storage in East Camp, Main Base, and

Rosamond storage unfts_[___[_- 19

6. Graph showng chlorlde content of well water,

Bdwards Ale Porce Base, Calffornla-_ 20

lPor prelintary release', all 1llustrations are at end of report. The page number indicates the first principal reference to that 11lustration in the text. 
Table 1. Cross index of Edwards A1r Force Base and

Geological Survey well numbers- 12

2. Pumpage from base-supply wells for calendar year 1964

3. Status of ground water in storage, Edwards

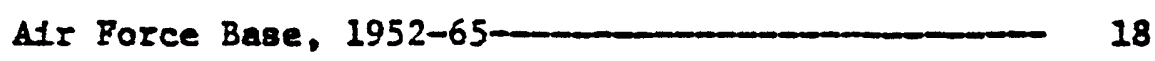

4. Chemical analyses of water-_ 21 
GROUND-WATER INVENTORY FOR 1964, EDWARDS AIR FORCE BASE, CALIFORRIA

\author{
By P. W. Glessner and S. G. Robson
}

\title{
SURMARY AND CONCLUSIONS
}

The water supply for Edwards Afr Force Base is ground water pumped from vells. Because recharge to the ground-rater supply is very small, constant surveillance of the quantity and quallty of the water stored in the underground basin 18 malntalned. This report, covering the perlod March 1964 through March 1965, 1s the elghth annual Inventory wade at the request of the Department of the A1r Porce. The results of the current study are sumartzed below.

1. Ground-water pumpage. -Ground-water pumpage by the base for all uses durtng the calendar year 1964 was about 7,220 acre-feet, wost of which was pumped from the Ma1n Base, Bast Camp, and North Base wells. 
2. Water-level fluctuations.--In the Main Base, East Camp, Rosamond, and North Muroc storage unfts, water levels declined about 0.2 to 9.3 feet in 1964 .

3. Ground water in storage.-Ground water in storage beneath and adjacent to the base in 1952 was estimated by Dutcher (1958, p. 40) to be $1,500,000$ acre-feet. Depletion of ground water in storage durlng the perfod March 1964 to March 1965 was about 15,800 acre-feet. Depletion durlag the pertod 1952-65 is about 135,300 acre-feet, an average of about 10,400 acre-feet per year.

4. Qual1ty of water.--Chemlcal analyses of water, collected annually from the principal base-supply wells, Indicate no appreciable deterforation of quallty. However, some deterforation occurred at North Base well 10N/9W-7A2.

The chloride content in water from well 10N/9W-7A2 (NB-2), as Indicated by a sample collected in 1964, was 960 ppw (parts per mi1110a). Experfence has shown that the chloride content in water from this well is related to the length of time the well is idle prtor to pumping for sampling. Efforts w11l be made in 1965 to determine the source of the water of bigh-chlorlde content. Analyses of water samples from well 9N/10W-16C2 show that mafor-constituent concentratfons have. decreased 70 to 85 percent from the values determined in 1963. 
5. New we118. - In May 1964 a new well was drilled at North Base to a depth of 500 feet; the yield was 2,200 gpm (gallons per minute). 
PURPOSE AND SCOPE OF THE CONTINUING INVENTORY

This report, for the perfod March 1964 through March 1965, is the elghth annual inventory of ground-water conditions at Edwards Afr Force Base, Los Angeles, Kern, and San Bernardino Counties, Calif. It was prepared by the U.S. Geological Survey in cooperation with the Air Force. The ares of Investigation is shown on f1gure 1.

The geology and groundwater resources of the Edwards Afr Force Base area were described by Dutcher and Worts (1958). Bas1c data are contained in a report by Dutcher, Bader, H11tgen, and others (1962). The continufng Inventary, submitted annually since 1958, has as its purpose the collection, analysis, and interpsetation of hydrologic data necessary to keep the Alt Force advised of current water-supply condftions on the base. 
The scope of the program requested by the Alr Force is as follows: (1) To continue periodic water-level measurements in key observation wello on the base to estimate the quantity of ground water in storage; (2) to continue to interpret chemical analyses of water from base wells to detect any changes in chem1cal quality of ground water and, in particular, to detect any deterforation of quality due to return of sewage effluent, downward movement of water of Inferior quality from the shallow water bodies, or migration of water of poor quality from local areas near the margins of the basins toward the base wells; and, as funds permit, to collect water samples pertodically from key wells to supplement the base sampling program; (3) to continue as technical adviser on water-supply problems at Edwards Afr Force Base; and (4) to prepare a brief annual report incorporating the findings made during the continuing inventory, including a sumbary of ground-water pumpage, an estimate of ground water in storage, hydrographs of water-level measurements, chemical analyses, and other basic data.

The work was done by the U.S. Geological Survey, Water Resources Division, under the immedlate supervision of I. C. Dutcher, chief of the Garden Grove subdistrict office, and under the general supervision of Walter Eofmann, district chief in charge of waterresources investigations in California. 
The well-numbering system was descrlbed by Dutcher and others (1962). For convenience of reference, table 1 presents a cross index of the well numbers used by Edwards Alr Force Base and those used by the Geological Survey. 
Table 1.-Cross index of Edwards Air Force Base and Geologleal Survey

we11 numbers

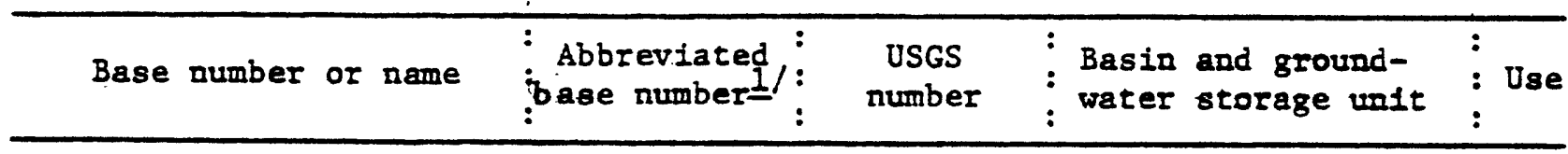

\section{Iancaster basin}

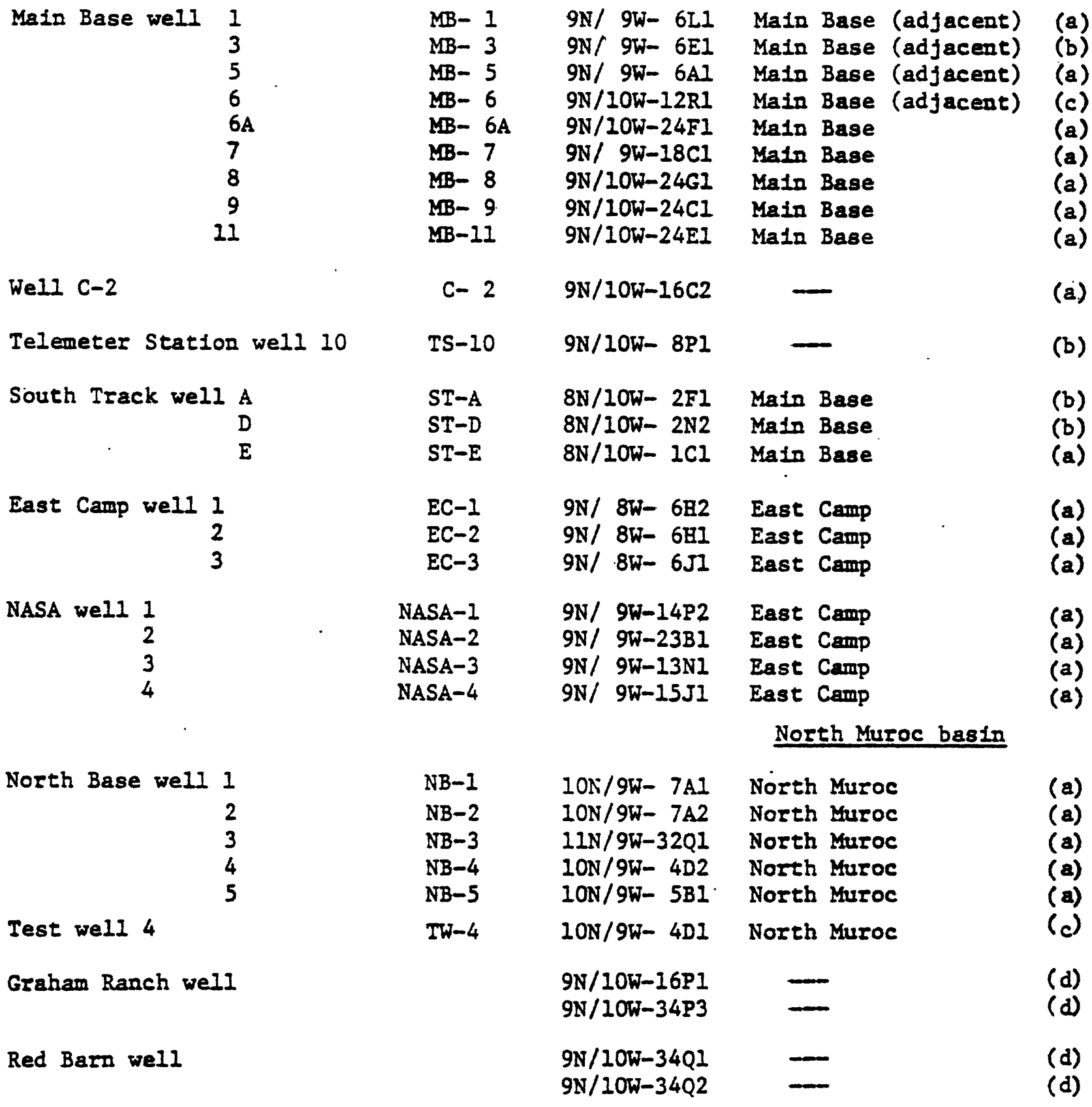

1. Symbol used in text.

a. Supply well.

b. Unused well. c. Recorder well.

d. Recreational well. 
The metered pumpage for the base in 1964 totaled 6,450 acrefeet (fig. 2). In addition monthiy records show that pumpage ranged from a January low of $85,851,000$ gallons (263 acre-feet) to an August h1gh of $330,014,000$ gallors (1,010 acre-feet). Purmage for all uses by the base in 1964, including both metered and estimated pumpage from the several ground-water basins and storage untes, is shown In table 2. Pumpage records for 1rrfgation and other uses outside the base in 1964 are not ava1lable. 
Table 2.--Pumpage from base-supply wells for calendar year 1964

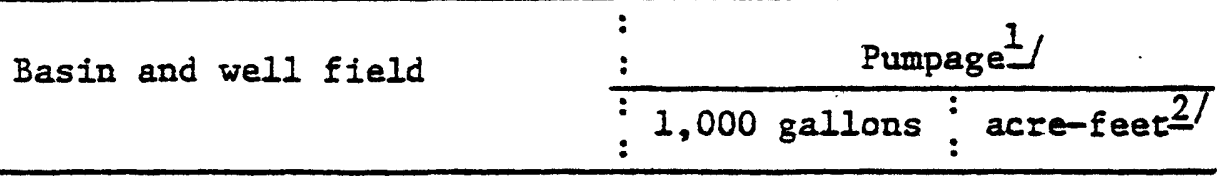

\section{Lancaster basin}

$\begin{array}{lrc}\text { Main Base wells } 6 \mathrm{~A}, 7,8,9 \text {, and II } & 1,060,000 & 3,260 \\ \text { Main Base wells I and } 5 & 39,800 & 122.3 \\ \text { East Camp wells I, 2, and } 3 & 432,000 & 1,320 \\ \text { NASA wells 1, 2, 3, and 4 } & 65,800 & 202 \\ \text { Recreation wells } 3 \text { / } & 250,000 & 767 \\ \text { Well C-2 } & 570 & 1.8 \\ \text { South Track well E } & 4,300 & 13.2 \\ & \text { Subtotal } 1,850,000 & 5,690\end{array}$

North Muroc basin

North Base wells 1, 2, 3, 4, and 5

$\frac{498,000 \quad 1,530}{2,350,000 \quad 7,220}$

1. All values rounded to three significant figures, or the nearest 0.1 acre-foot.

2. One acre-foot equals 325,851 gallons.

3. Pumpage is estimated; the water is not used for base supply, and the pumpage is not shown on figure 2. 
Water levels were measured blannually in nearly 100 wells on and near the base. Recorders were operated on four wells to obtatn continuous records of water-level fluctuations. Water-level records are on file in the office of the Geological Survey in Garden Grove, Calff., and are available on request.

The water-level-contour map (EIg. 3) shows three prlocipal pumplng depressions near Edwards Afr Force Base. The largest is centered about 10 miles east of Lancaster, a second depression is near wells $9 \mathrm{~N} / 10 \mathrm{~W}-24 \mathrm{EI}$ and $24 \mathrm{FI}$ in the Main Base well fleld, and the third pumping depression is in the North Muroc storage unit near well IIN/9W-24Q1.

In most of the area, ground-water levels start to decline in the early spring and continue to decline unt11 about September, when a recovery begins, as shown by the hydrographs on f1gure 4. Por the period of record, the highest annual water level in most wells has been lower than the highest level for the prevlous year. Slmilarly, the lowest annual water level also has been lower each succeeding year. 
During the period of this report, the decline of water levels in the North Muroc storage unit ranged from 0.44 ta 3.73 feet, based on water levels in wells $10 \mathrm{~N} / 9 \mathrm{~W}-24 \mathrm{~A} 2$ and $10 \mathrm{~N} / 9 \mathrm{~W}-4 \mathrm{DI}$. In the East Camp area, the decline ranged from 1.74 to 3.60 feet, and in the Rosamond storage unit, the decline ranged from 0.20 to 6.86 feet. In the Main Base storage unit, the decline ranged from 1.78 to 9.34 feet. 
GROUND WATER IN STORAGE, 1964-65

The quantity of ground water in storage in 1952 in the groundwater storage units of Edwards Afr Force Base (fIg. 3) was estimated by Dutcher (1958, p. 40). Table 3 shows the estimated yearly depletion for the period 1952-65, using the same assumptions and data sources. 


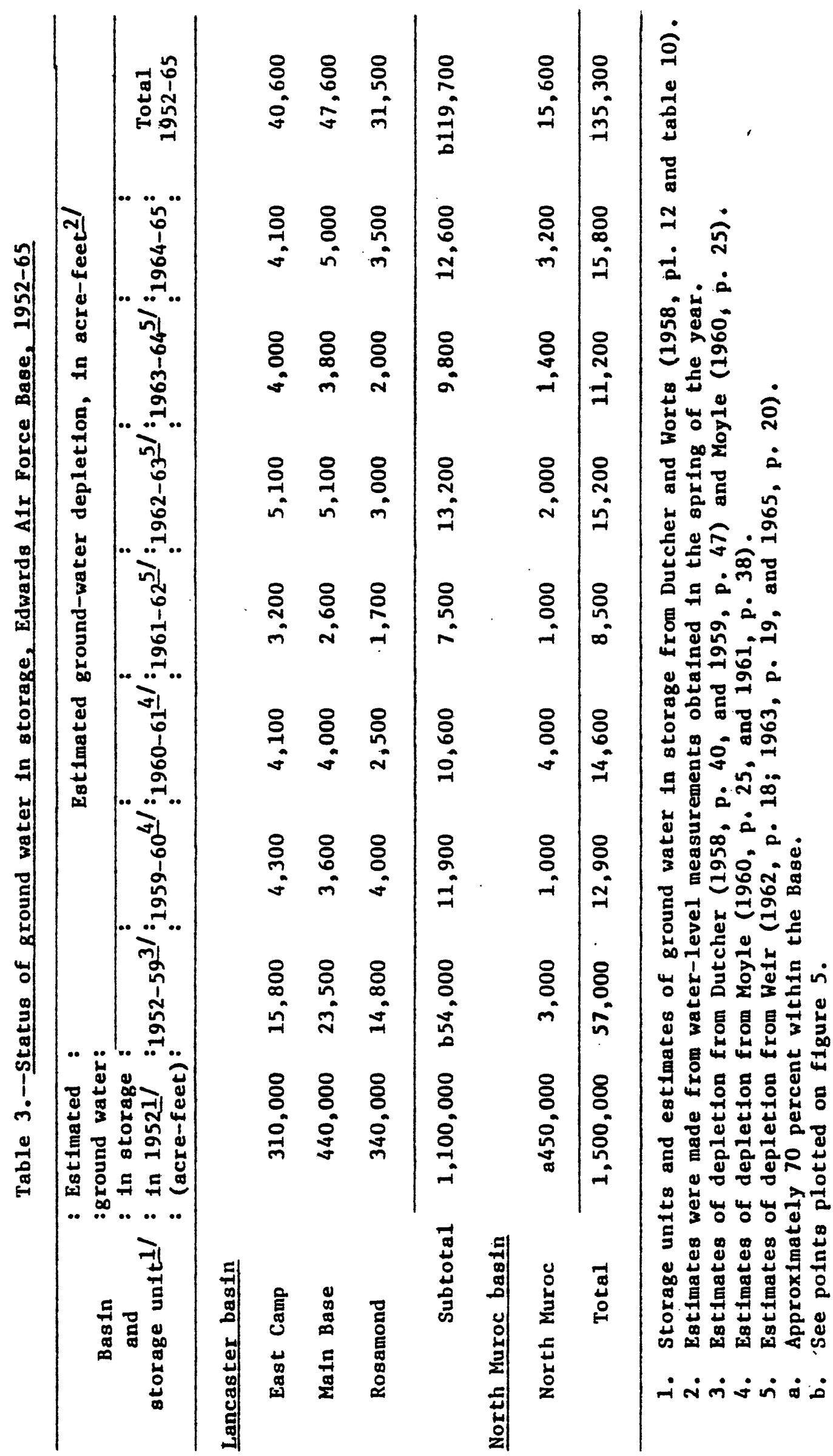


The estimnted depletion of ground water, between March 1964 and March 1965, is about 15,800 acre-feet (table 3) in the East Camp, Maln Base, Rosamond, and North Muroc storage units. This depletion is 4,600 acre-feet more than that for the 1963-64 perfod and is the record high.

The total depletion for 1952-65, as shown by table 3 , is about 135,300 acre-feet. Depletion in all storage units, except North Muroc, for the same period was 119,700 acre-feet (table 3 and $\mathrm{fIg} .5$ ), which represents an average water-level decline of 30 feet for the 13-year period. 


\section{QUALITY OF WATER}

Water samples hàve been collected annually from base wells for chemical analysis, Except in the area of wells 9N/10W-16C2 (C-2), 10N/9W-7A2 (NB-2), and 9N/8W-6H2 (EC-1), the analyses 1ndicated no 81galficant changes in the chemical quallty of the water on the base. The quality of the vater from well $9 \mathrm{~N} / 10 \mathrm{~W}-16 \mathrm{C} 2$ showed an improvemant In 1964. The concentrations of wost of the mafor constituents vere about 70 to 85 percent less than in 1963. The quallty of the water from well 10N/9W-7A2 deterforated somewhat in 1964. The sodium and the chloride contents increased from $515 \mathrm{ppm}$ and $735 \mathrm{ppm}$ to $610 \mathrm{ppm}$ and $960 \mathrm{ppm}$, respectively. This deterioration 18 also reflected by the chlorlde content of water from well 10N/9W-7Al (f1g. 6). The chlortde content of water from well $10 \mathrm{~N} / 9 \mathrm{~W}-742$ usually increases when the well has not been pumped for several days prior to sampling. Efforts will be made in 1965 to determine the source of the water of high-chloride content. The nitrate content of the water from supply well 9N/8W-6H2 lacreased from $8.5 \mathrm{ppm}$ in 1963 to $20 \mathrm{ppm}$ in 1964. Additfonal water samples w11l be taken in 1965 to determine If this quality change is aigatflcant. 
Records of chemical analyses made prior to 1964 are tabulated in reports by Dutcher, Bader, Hiltgen, and others (1962, table 7 , p. 184-209), Dutcher and Worts (1958, table 9, p. 189), Dutcher (1959, table 8, p. 52-56), Moyle (1960, table 6, P. 29-31, and 1961, table 5, p. 40-42), and WeIr (1962, table 5, p. 21-22, 1963, table 5, p. 22-23, and 1965, table 4, p. 23-24). 
NEW WELLS

To satisfy the demand for a water supply at the base, a new well was drilled is the North Base fleld in May 1964. The well was drilled to a depth of 500 feet, and a 16-inch casing, perforated from 100 to 500 feet, was installed. The static water level in this area is about 75 feet below the land surface. The 108 of the well is shown on the following page. 
10N/9W-5B1 (NB-5). Dr1lled by Evans Bros., Lancaster, Cal1f. Alt1tude about 2,290 feet above mean sea level. 16-1nch casing, 0-500 feet; perforated 100-500 feet; gravel packed.

\begin{tabular}{|c|c|c|}
\hline & $\begin{array}{c}\text { Th1 cieness } \\
\text { (feer) }\end{array}$ & $\begin{array}{l}\text { Depth } \\
\text { (Eeet) }\end{array}$ \\
\hline Surface 8011 & 8 & 8 \\
\hline Sand - & 52 & 60 \\
\hline $\begin{array}{l}\text { Sand and gravel, with clay streaks } \\
\text { Sand, gravel, and boulders; very l1ttle clay - }\end{array}$ & $\begin{array}{r}186 \\
23\end{array}$ & $\begin{array}{l}246 \\
269\end{array}$ \\
\hline Sand and sandy brown clay - & 6 & 275 \\
\hline Clay, brown, with some sand - & 19 & 294 \\
\hline Sand and boulders & 12 & 306 \\
\hline Sand, gravel, and boulders & 14 & 320 \\
\hline Sand, gravel, and brown clay & 28 & 348 \\
\hline Sand and gravel, with thin streaks of brown clay - & 37 & 385 \\
\hline Sand, hard, with thin streaks of clay - & 73 & 458 \\
\hline Sand, with streaks of clay & 27 & 485 \\
\hline Sand - & 15 & 500 \\
\hline
\end{tabular}


The graph below shows the results of a 48-hour pumping test at the new supply well. The well ylelded 2,200 gpm with 91 feet of drawdown, which is excellent in comparison with yields of other wells in the area.

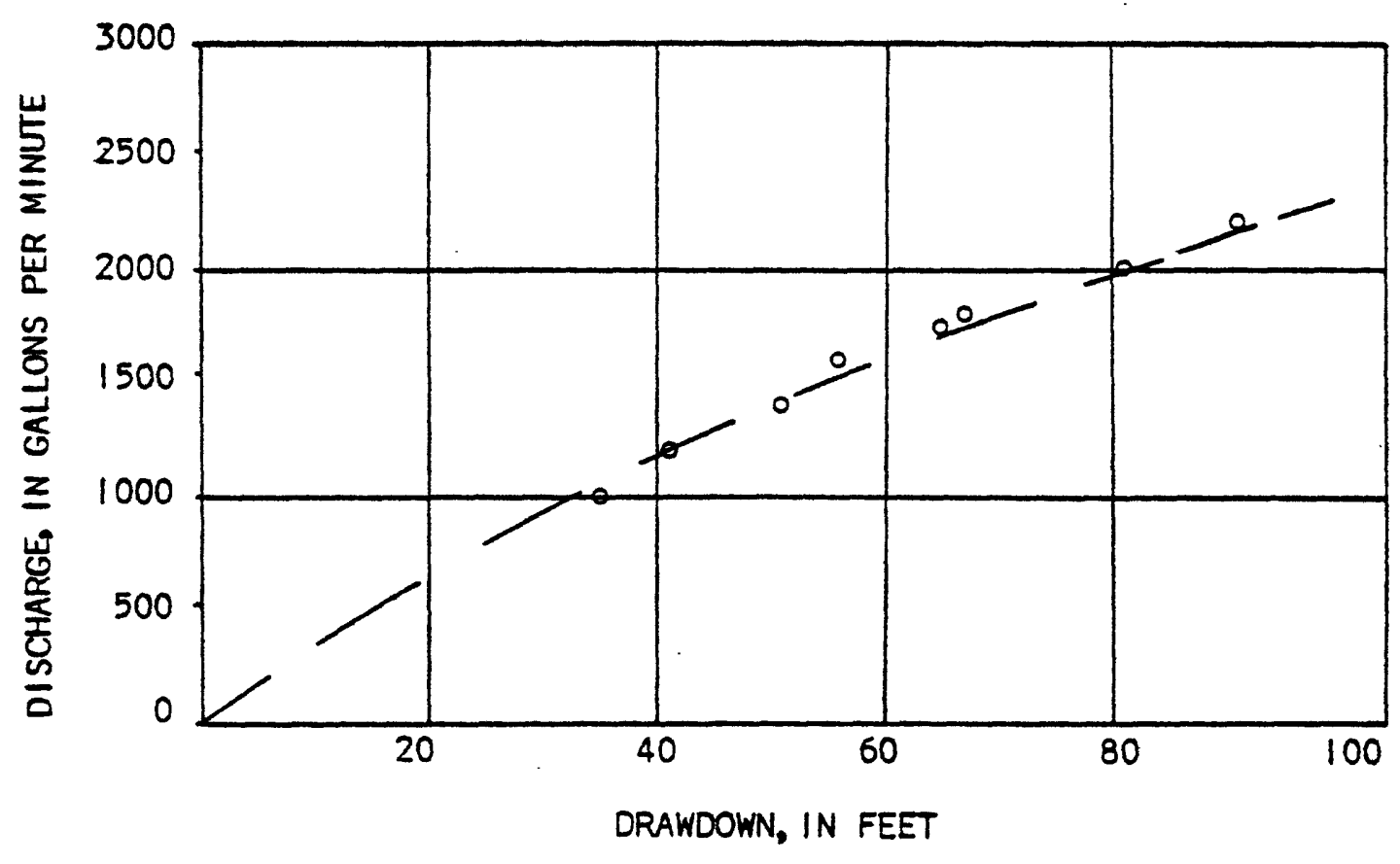

GRAPH OF PUMPING TEST FOR SUPPLY WELL ION/9W-5BI (NB-5) 
Because of prevalling drought conditions in southern California and the long history of declining water levels in the desert reglon, it is important that the Air Force coatinue the program of monitoring water levels in observation and supply wells. In som of the key observation wells on the base, the water levels bave declined below the bottom of the wells; otber wells bave been plugged with debris. This gradual but continuting 108 of observation wells reduces the data avallable to appralse the adequacy of the ground-water supply In the area. Therefore, a program should be inltiated to restore or reclaim the dry and plugged observation wells so that perlodic masurements of water level can be contlnued.

As a part of the continuing progran at the base in fiscal year 1966, the Geological Survey w1Il prepare a summary of the work neaded to restore, clean, or deepen some of the observation wells previously measured regularly. Cost estimates for any work which cannot be accomplished by the Survey w11 be included. 
REFERENCES

Dutcher, I. C., 1958, Ground-water inventory for 1954-57, Edwards Air Force Base, California: U.S. Geol. Survey open-file rept., 63 p. 1959, Ground-water Inventory for 1958, Edwards Alr Force Base,

California: U.S. Geol. Survey open-file rept., 69 p.

Dutcher, I. C., Bader, J. S., Hiltgen, W. J., and others, 1962, Data

on wells in the Edwards Air Force Base area, California:

California Dept. Water Resources Bull. 91-6, 209 p.

Dutcher, I. C., and Worts, G. F., Jr., 1958, Geology and ground-water appraisal of Edwards Air Force Base and vicinity, California:

U.S. GeoI. Survey open-file rept., 229 p.

Moyle, W. R., Jr., 1960, Ground-water inventory for 1959, Edwards Afr

Force Base, California: U.S. Geol. Survey open-file rept., 35 p. 1961, Ground-water Inventory for 1960, Edwards Air Force Base,

California: U.S. Geol. Survey open-file rept., 45 p.

U.S. Department of Health, Education, and Welfare, Public Health

Service, 1962, Public Health Service Drinking Water Standards, 1962:

Public Health Service Pub. 956, 61 p.

We1r, J. E., Jr., 1962, Ground-water Inventory for 1961, Edwards Air Force Base, Calffornia: U.S. Geol. Survey open-file rept., 54 p. 1963, Ground-water Inventory for 1962, Edwards Afr Force Base,

Callfornia: U.S. Geol. Survey open-file rept., 42 p. 1965, Ground-water inventory for 1963, Edwards Air Force Base,

Californla: U.S. Geol. Survey open-f1le rept., 28 p. 
FIGURE I

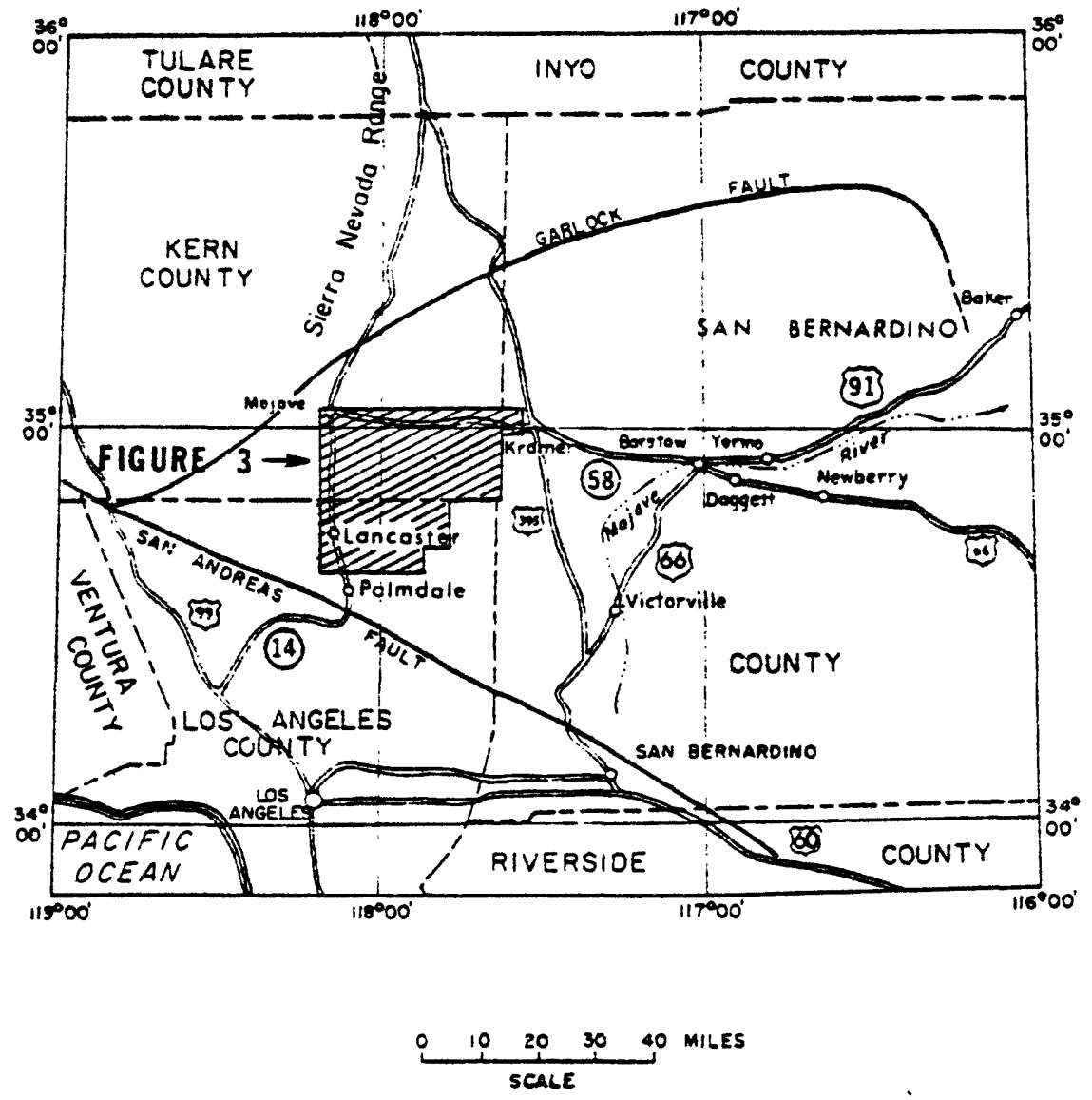

FIGURE 1.- MOp of port of southern Colifornio showing oreo described in this report 


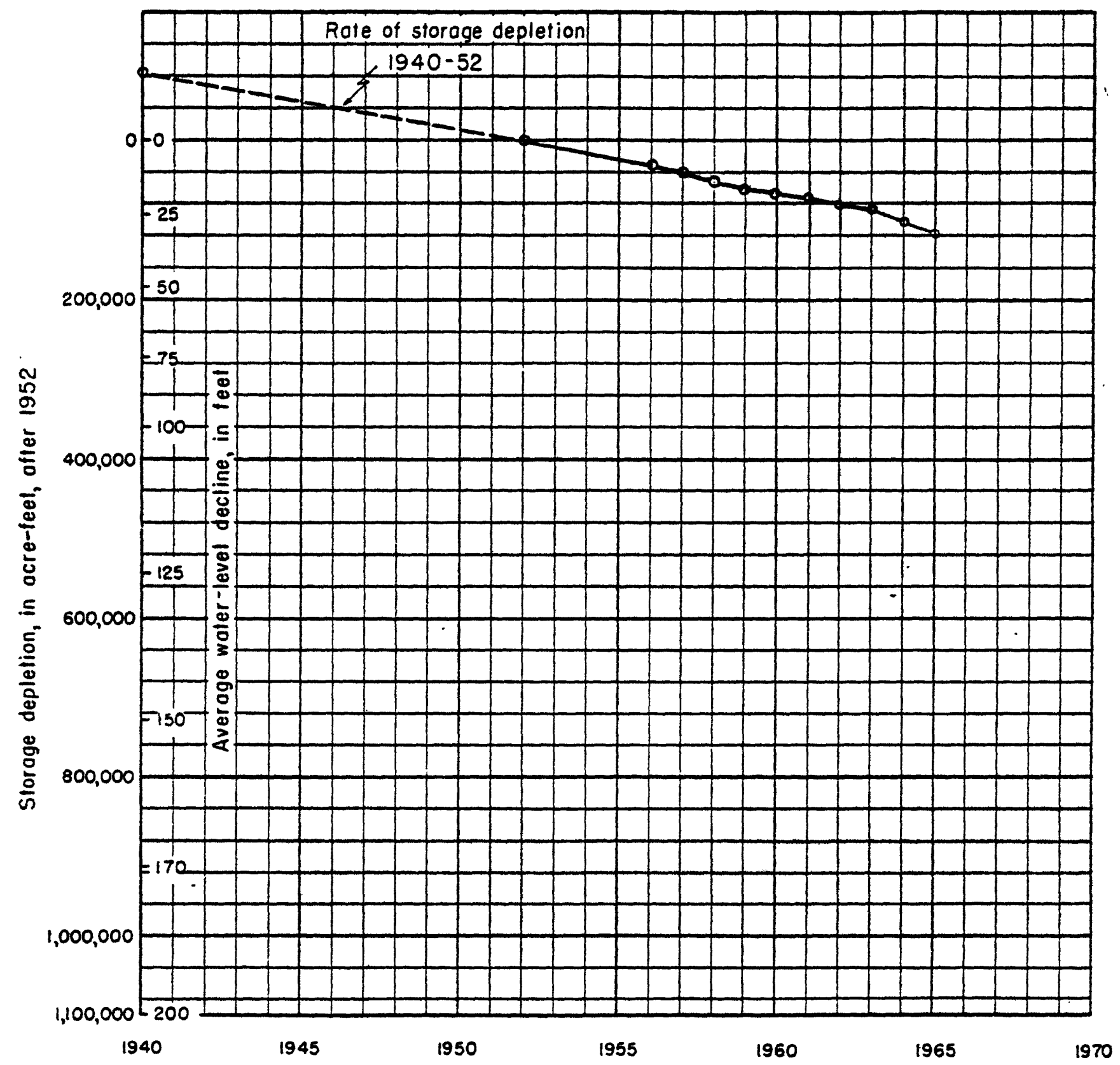

ESTIMATED TOTAL DEPLETION OF GROUND WATER IN STORAGE IN EAST CAMP, MAIN BASE, AND ROSAMOND STORAGE 


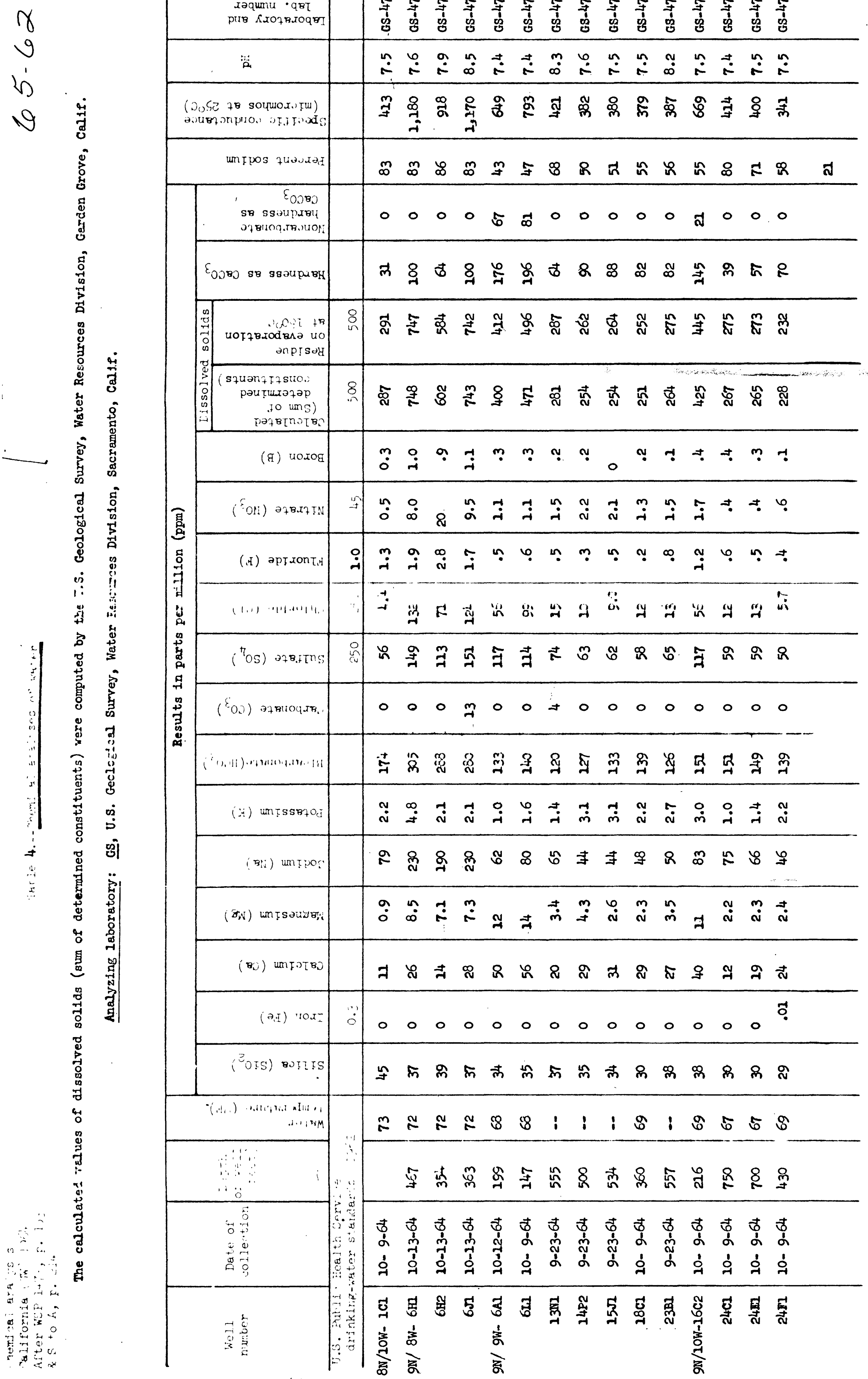




\begin{tabular}{|c|c|c|c|c|c|}
\hline 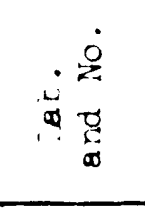 & 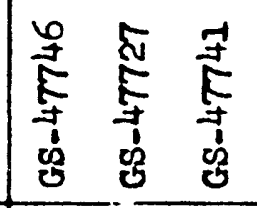 & 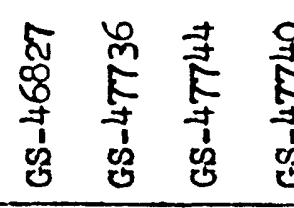 & $\begin{array}{l}9 \\
\substack{0 \\
+} \\
0 \\
0\end{array}$ & & 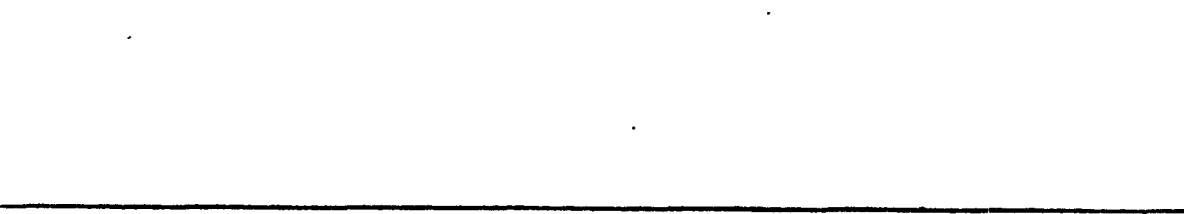 \\
\hline 霷 & 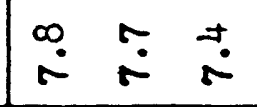 & 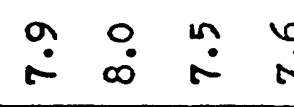 & $\stackrel{\circ}{\circ}$ & & \\
\hline 它 & స్ల్ స్ల స్ల & 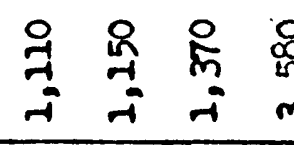 & 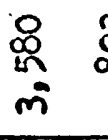 & & \\
\hline 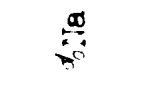 & in $\rightarrow a$ & 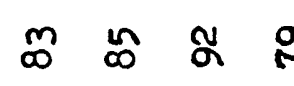 & $q$ & & มี \\
\hline 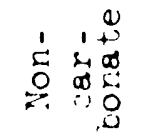 & $\begin{array}{lll}0 & 0 & 0\end{array}$ & 000 & $\stackrel{n}{\sim}$ & & \\
\hline 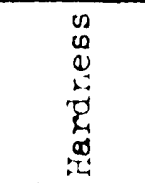 & 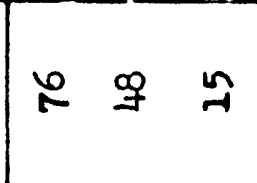 & ఉే పే & 表 & & \\
\hline 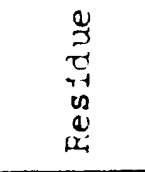 & 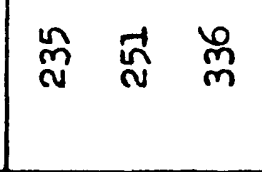 & 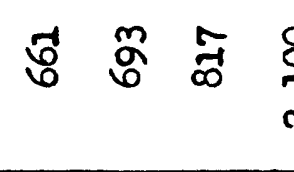 & 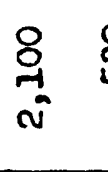 & 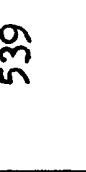 & \\
\hline$\underbrace{5}_{12}$ & 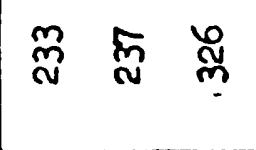 & 势 品 & $\begin{array}{l}\text { Oे } \\
\text { ò } \\
\text { ì }\end{array}$ & 品 & \\
\hline$"$ & 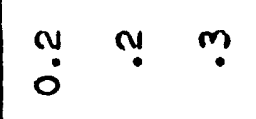 & $\uparrow \subsetneq \dddot{\varphi}$ & $\because$ & & \\
\hline$\underbrace{m}$ & 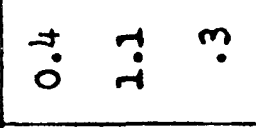 & $\stackrel{m}{m} \stackrel{9}{9}$ & $\mathbb{N}$ & ฯ & \\
\hline$i_{4}$ & 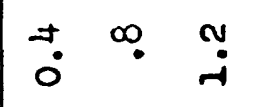 & $\begin{array}{llll}+ & 0 & 0 & 0\end{array}$ & $\stackrel{\infty}{\infty}$, & $m$ & . \\
\hline$\because$ & 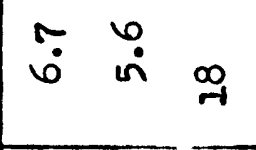 & 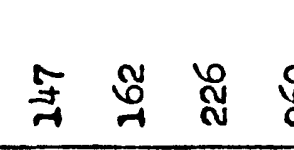 & 8 & \& & \\
\hline 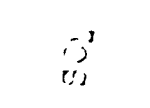 & 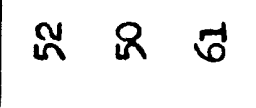 & 吉 ちす & $\overrightarrow{ \pm}$ & & \\
\hline$\beta^{\prime \prime}$ & 00 & $0 \quad 0 \quad 0$ & $\circ$ & 。 & \\
\hline$\overbrace{\substack{m \\
c^{m}}}$ & 馬串 品 & 胥 & 志 & 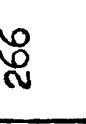 & \\
\hline$x$ & 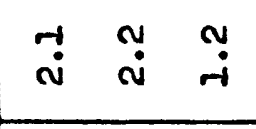 & i & $\stackrel{9}{+}$ & it & \\
\hline$\stackrel{\infty}{\approx}$ & 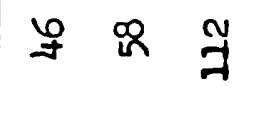 & 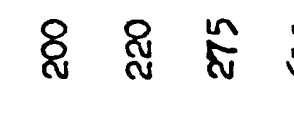 & 앙 & 氶 & \\
\hline$\stackrel{\infty}{2}$ & $\stackrel{m}{m} \underset{i}{m} r$ & $\stackrel{0}{f} \stackrel{n}{f}$ & $\stackrel{\infty}{\sim}$ & ָั & \\
\hline$\infty$ & 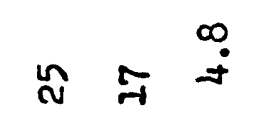 & $\stackrel{n}{n} \stackrel{n}{*}$ & 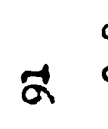 & $\infty$ & \\
\hline$\underbrace{0}_{4}$ & $\circ 0^{-1}$ & $\overrightarrow{0}$ & $\circ$ & $\circ$ & \\
\hline $\begin{array}{l}0^{v} \\
i_{i}^{2}\end{array}$ & 足 đ్ల స & s 尺 & 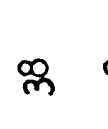 & $\stackrel{\sim}{\sim}$ & \\
\hline${ }_{0}^{n_{1}}$ & 8 추 & « \& & 8 & ? & 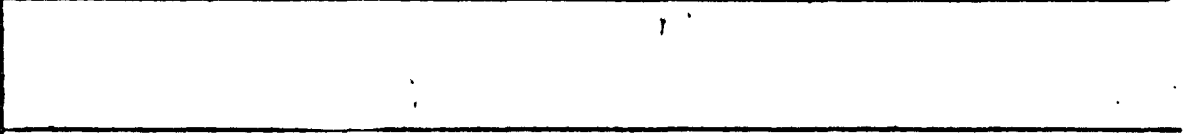 \\
\hline 涪 & 总空空 & 宗总忿 & $\stackrel{8}{8}$ & 究 & \\
\hline 要 & 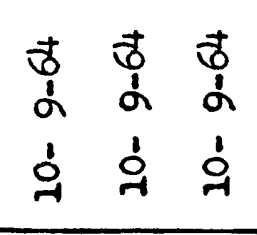 & 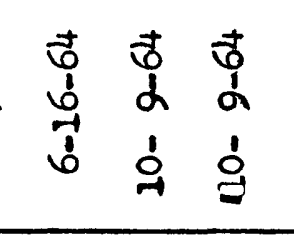 & $\begin{array}{l}\text { ț } \\
\alpha \\
\dot{1} \\
\vdots\end{array}$ & $\begin{array}{l}0 \\
0 \\
\alpha \\
\delta \\
\delta \\
0\end{array}$ & \\
\hline $\begin{array}{l}\dot{0} \\
\dot{z} \\
\overrightarrow{0} \\
3\end{array}$ & 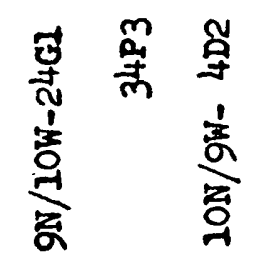 & 蛋 蚛 & ใิ & 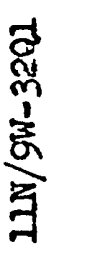 & \\
\hline
\end{tabular}




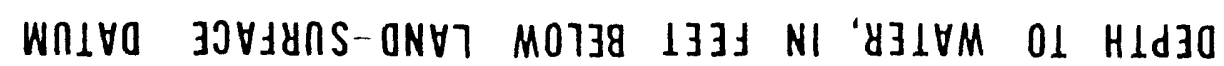

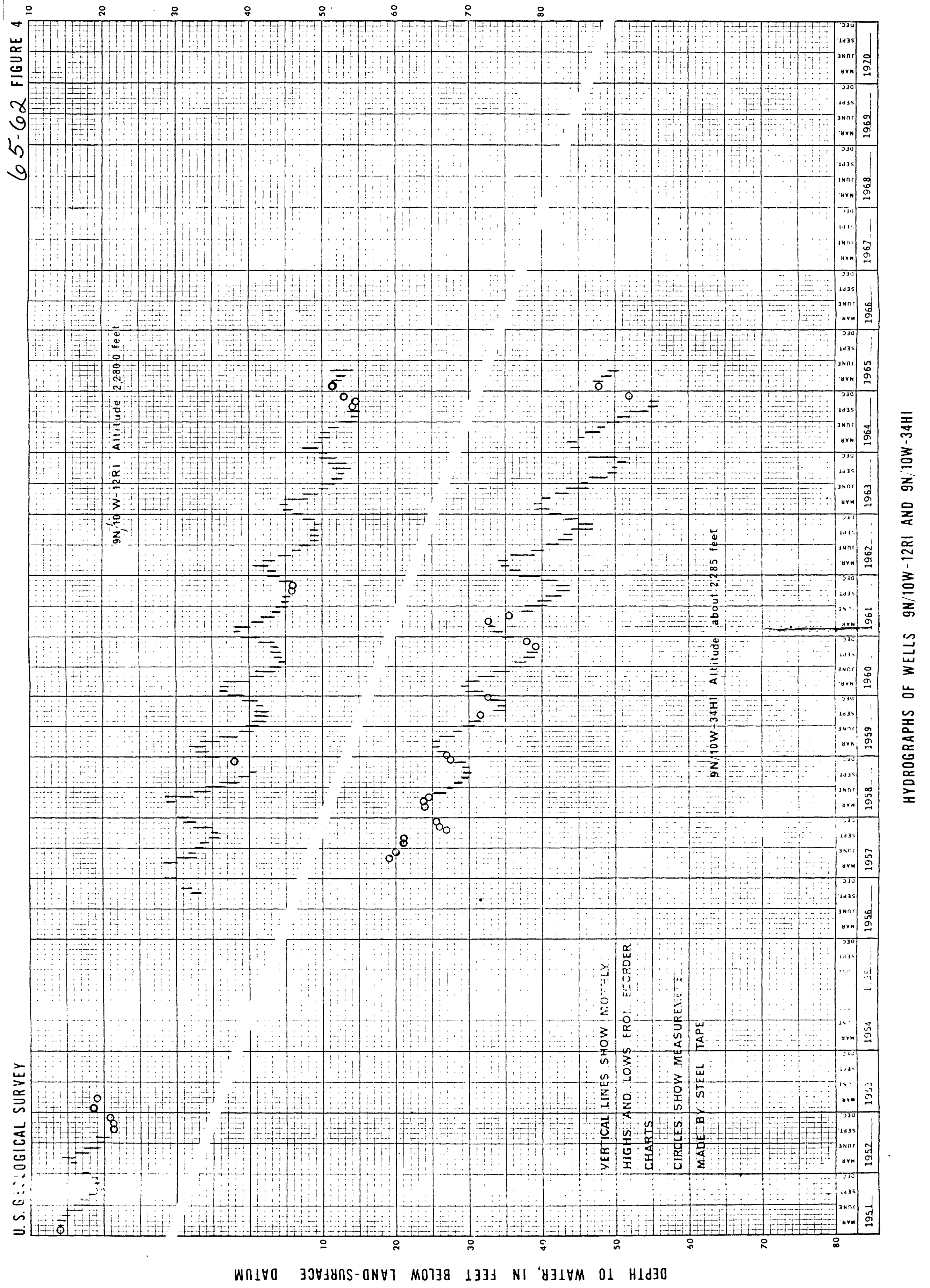




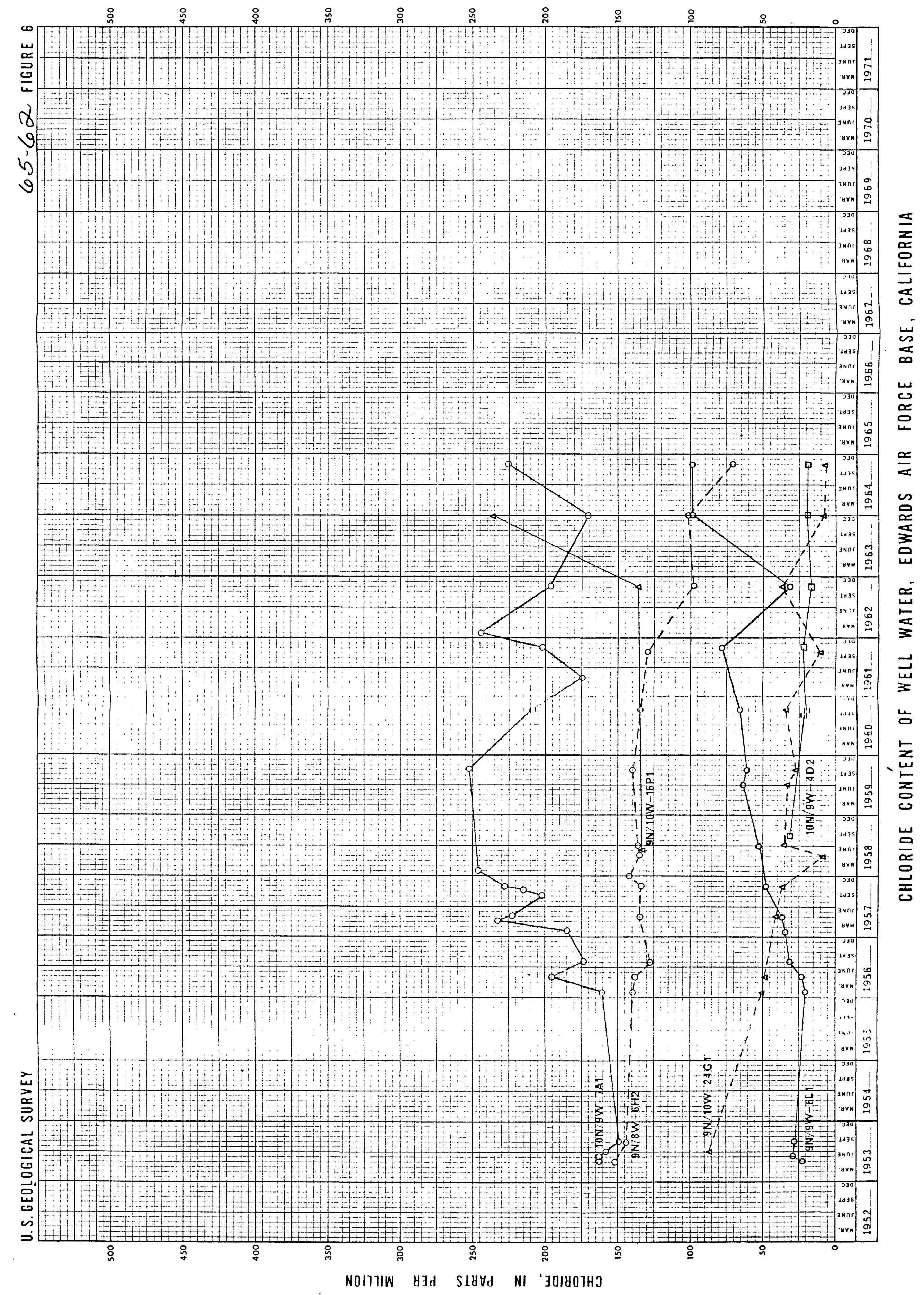

